Ks. Krzysztof BARDSKI

(Warszawa, UKSW)

\title{
PATRYSTYCZNA EGZEGEZA ALEGORYCZNA - UŻYCIE CZY NADUŻYCIE TEKSTU BIBLIJNEGO?
}

W ostatnich latach wzrasta zainteresowanie starożytną egzegezą alegoryczną również w kontekście badań biblijnych. Wynika to w pewnej mierze $\mathrm{z}$ rozszerzenia spectrum metod analizy tekstu biblijnego, jakie dokonało się w ostatnich dziesięcioleciach ubiegłego wieku. Dokument Papieskiej Komisji Biblijnej z 1993 r. pt. Interpretacja Biblii w Kościele obok metody historycznokrytycznej, która uważana byla za podstawową, przez niektórych biblistów nawet za jedyną naukowo uprawnioną do badań nad tekstem Pisma Świętego, wymienia również inne podejścia, określane często wspólnym mianownikiem metod synchronicznych (np. narratologia, krytyka retoryczna, semiotyka, metoda „kanoniczna”, metody odwołujące się do żydowskich tradycji interpretacyjnych lub do oddziaływania tekstu). W tym kontekście zwrot ku metodom interpretacyjnym stosowanym przez Ojców Kościoła jawi się nie tylko jako badanie pewnego zjawiska o charakterze historycznym, lecz jako próba kontynuacji w kontekście współczesnej biblistyki takiego podejścia do tekstu natchnionego, jakie charakteryzowało nie tylko okres patrystyczny, lecz było obecne również wśród monastycznych pisarzy średniowiecza i w jakimś sensie znajduje swój wyraz w akomodacjach stosowanych również w epokach późniejszych.

Na początek posłużmy się przykładem. Podczas przygotowań do beatyfikacji Matki Teresy z Kalkuty w październiku 2003 r., oficjalny plakat, przygotowany $w$ różnych językach $w$ związku $z$ tą uroczystością, zawierał jako motto słowa papieża Jana Pawła II: „W czynach i słowach Matki Teresy Chrystus znowu przechodzi drogami dzisiejszego świata jako dobry Samarytanin". Cytat ten w swojej istocie nawiązuje do szeroko rozpowszechnionej w starożytnym chrześcijaństwie chrystologicznej interpretacji przypowieści o dobrym Samarytaninie (Łk 10, 30-35). Na plaszczyźnie sensu dosłownego, przypowieść o miłosiernym Samarytaninie ( $€$ k 10, 30-37) stanowiła fikcyjne opowiadanie, mające na celu uzmysłowienie słuchaczom, że każdy człowiek, niezależnie od rasy i przynależności narodowej, jest naszym bliźnim oraz zobrazowanie - na przykładzie cudzoziemca - właściwej postawy prawego Izraelity wobec czlowieka 
potrzebującego pomocy. Poszczególne motywy literackie opowiadania, takie jak zbójcy, zdarta szata, osiol, oliwa i wino, gospoda, dwa denary, itd. miały znaczenie pomocniczc. Nie były one w zamyśle autora nośnikami innych treści, lecz tylko rekwizytami, mającymi podnieść poziom ekspresyjności opowiadania. Skoro jednak prześledzimy historię interpretacji przypowieści w starożytnym i średniowiecznym chrześcijaństwie, okaże się, że wokół wymienionych powyżej motywów literackich narosło wiele skojarzeń, nie mających wiele wspólnego $z$ intencją autora. Ojcowie Kościola, odwołując się do Chrystusowego wezwania, by stać się Jego naśladowcami (Mt 16, 24 i paralelne) oraz w oparciu o ostatnie słowa przypowieści (Idż $i$ czyń podobnie), widzieli w postaci miłosiernego Samarytanina symbol Chrystusa i w tym kluczu próbowali odczytywać pozostałe motywy literackic. I tak nieszczęśnik, którego napadli zbójcy, stał się w wyobraźni tradycji symbolem ludzkości zranionej przez szatana. Jego stan (zostawili go na pót umarłego) oznaczał konsekwencje grzechu pierworodnego. Kapłan i lewita idący drogą oznaczali wszystkich, którzy przed narodzeniem Zbawiciela nie byli w stanie uratować człowieka. Dopiero Syn Boży, który podjął wędrówkę tą samą drogą, którą przemierzał człowiek, co oznacza tajemnicę wcielenia, pochylił się nad nim i opatrzył jego rany. Zalał je oliwą i winem, co w wyobraźni starożytnej tradycji stało się symbolem sakramentów chrztu i Eucharystii oraz zawiózł do gospody, która oznaczała Kościół. Dwa denary dane gospodarzowi doczekały się wielorakich skojarzeń. Dla jednych Ojców Kościoła oznaczały Stary i Nowy Testament, które stanowią pomoc, dzięki której człowiek może przetrwać aż do powtórnego przyjścia Zbawiciela, dla innych zaś przykazania miłości Boga i bliźniego, które stanowią kwintesencję nauki pozostawionej Kościołowi przez Chrystusa.

Przedstawiona powyżej interpretacja leży u podstaw wypowiedzi papieża Jana Pawła II, aczkolwiek nie nawiązuje on do szczegółowych skojarzeń alegorycznych, rozwiniętych przez Ojców Kościoła i pisarzy średniowiecznych. Czy jednak skojarzenia te, jak również bogata spuścizna alegorystyki, stanowią tylko swoistą ,,manierę”, nie zasługującą na analizę hermeneutyczną? Czy są nadużyciem tekstu biblijnego, którego autor chcial powiedzieć coś zupełnie innego? Wydaje się, że należałoby wziąć pod uwagę szereg argumentów, które mogłyby wskazywać na to, że mimo wszystko ponaddoslowne odczytywanie Biblii może być aktualne również w czasach dzisiejszych.

Po pierwsze, interpretacja ponaddosłowna Pisma Świętego stanowi jeden z najbardziej trwałych elementów tradycji Kościoła i wycisnęła swoje piętno na wielu aspektach jego życia. Jej refleksy znajdujemy w liturgii, mistyce, ale przede wszystkim jest ważnym czynnikiem oddziaływania duszpasterskiego, czy to w katechetyce, czy w homiletyce. Stąd wydaje się rzeczą nad wyraz pożądaną podjęcie prób naukowego opracowania tej metody interpretacji Biblii, celem wyświetlenia nie tylko szans i bogactwa, jakic zc sobą niesie, ale również niebezpieczeństw. 
Po drugie, niektóre dokumenty Urzędu Nauczycielskiego Kościoła wskazują na istotne miejsce ponaddosłownej interpretacji Biblii w życiu Kościoła. Należy tu wspomnieć przcde wszystkim Katechizm Kościoła Katolickiego, który podkreśla wielość sensów Pisma Świętego, cytując nawet słynny średniowieczny dwuwiersz łaciński autorstwa Augustyna z Dacji († 1285): „Littera gesta docet, quid credas allegoria, moralis quid agas, quo tendas anagogia"l. Katechizm powtarza również ważne stwierdzenie Soboru Watykańskiego II: „Aby dobrze interpretować Pismo Święte, trzeba zwracać uwagę na to, co autorzy ludzcy rzeczywiście zamierzali powiedzieć i co Bóg chciał nam ukazać przez ich słowa"2. Magisterium Kościoła słusznie na pierwszym miejscu wymienia wyrazowy sens Biblii, uwzględniający intencję autora natchnionego, pozostawia jednak - w ostatnich słowach cytatu - szeroka perspektywę hermeneutyczną dla interpretacji ponaddosłownej. Ponadto znaczenie ponaddosłownego sensu Biblii zostało podkreślone w odnośnym rozdziale dokumentu Papieskiej Komisji Biblijnej pt. Interpretacja Biblii w Kościele $^{3}$, a zwłaszcza w części poświęconej interpretacji Pisma Świętego w tradycji Kościoła ${ }^{4}$. Czytamy tam m.in.: „Poza tym zwróceniem uwagi na tekst w jego picrwotnym oryginalnym kontekście Kościół liczy na egzegetów ożywionych tym samym Duchem, który inspirował Pismo Święte, żeby „możliwie wielka liczba sług Słowa Bożego była w stanie skutecznie dostarczyć ludowi Bożemu pokarmu Pism"s. Słowa powyższe zawierają wyraźną zachętę do takiej pracy badawczej nad tekstem biblijnym, która nie ograniczałaby się wyłącznic do poszukiwań sensu dosłownego, lecz była otwarta na bogactwo znaczeń ponaddosłownych.

Po trzecie, wspólczesne teorie hermeneutyczne (zwlaszcza tzw. nowa hermeneutyka Heideggera) oraz krytyka literacka, zastosowane do badań nad tekstem biblijnym, wyłoniły nowe perspektywy w dziedzinie odczytywania sensu wypowiedzi. Strukturalizm, intertekstualizm, a nawet dekonstrukcjonizm, zapraszają do nowego spojrzenia na problem sensu Pisma Świętego i niejednokrotnie podważają zasadność klasycznego podziału na sens dosłowny $i$ alegoryczny, wskazując na pewne wymiary sensu obecne w tekście, lecz nie należące do kategorii intencji autora.

Starając się z perspektywy naukowej stawić czoła wyzwaniu, jakie rzuca współczesnemu człowickowi starożytna i średniowieczna alegorystyka chrześ-

${ }^{1}$ Por. Katechizm Kościola Katolickiego (= KKK) 115-119.

2 Tamże 109; Dei Verbum 12.

${ }^{3}$ Por. Interpretacja Biblii w Kościele. Dokument Papieskiej Komisji Biblijnej z komentarzem biblistów polskich, przeklad i redakcja R. Rubinkiewicz, Rozprawy i Studia Biblijne 4, Warszawa 1999, 63-65 (Sens duchowy).

${ }^{4}$ Por. tamze, $80-88$.

${ }^{5}$ Tamże. 87. W cudzyslowie cytat z: Divino afflante Spiritu, 24 (Enchiridion Biblicum [= EB] nr 551 i 567); Dei Verbum 23. 
cijańska, wydaje nam się jednak istotne wprowadzenie pewnych doprecyzowań terminologicznych, spośród których dwa uważamy za najważniejsze.

Po pierwsze, sądzimy, że najbardziej adekwatnym określeniem zjawiska alegorystyki jest pojęcie sensu ponaddosłownego. Termin ten został wprowadzony do języka polskiego w Katolickim Komentarzu Biblijnym, będącym polskim opracowaniem The New Jerome Biblical Commentary ${ }^{6}$, jako kalka językowa angielskiego określenia more-than-literal. Sądzimy, że rozróżnienie sens dostowny oraz sens ponaddostowny w sposób należyty podkreśla fundamentalną rolę sensu dosłownego, równocześnie zaś sugeruje nadbudowę semantyczną właściwą niektórym interpretacjom zaliczanym do sensu tradycyjnie nazywanego duchowym, mistycznym lub alegorycznym.

Po drugie, sam proces interpretacji tekstu posiada w przypadku poszukiwania sensu dosłownego radykalnie inny charakter niż w przypadku swoistej twórczości interpretacyjnej, jaka towarzyszy powstawaniu sensu ponaddosłownego. Dlatego też może wydać się zasadne ograniczenie terminu egzegeza do badań, mających na celu wydobycie znaczenia dosłownego tekstu, zaś lektura nakierowana na znaczenie ponaddosłowne mogłaby zostać nazwana interpretacja bądź odczytywaniem.

Rodzi się jednak pytanie, które może nurtować zwłaszcza człowieka wierzącego: jeżeli sens ponaddosłowny jest tworem powstałym w wyobraźni określonego czytelnika, to jaka jest jego obowiązywalność? Na ile należy go traktować jako sens Biblii? Na ile, i czy w ogóle, zawiera orędzie Boże? O ile natchnienie tekstu biblijnego stanowi akt o charakterze historycznym i skończonym, o tyle natchnienie - jeśli tak można to określić - związane $\mathrm{z}$ ponaddosłownym odczytaniem określonego fragmentu Biblii ma zupełnie inny charakter. Polega ono na czytaniu i interpretowaniu Pisma Świętego w tym samym Duchu, w jakim zostało napisane $e^{7}$. Nie dysponujemy jednak jasnymi i jednoznacznymi kryteriami, które mogłyby określić, czy dane duchowe odczytanie tekstu dokonano $w$ tym samym Duchu, czy też nie. $\mathrm{Z}$ drugiej strony nie możemy jednak stwierdzić, że jest ono całkowicie pozbawione wartości. Magisterium Kościoła jest w tej kwestii bardzo powściągliwe. Dlatego też, czytając Biblię w sposób ponaddosłowny, konieczna jest pewna świadomość pluralizmu znaczeniowego i tolerancji dla innych rozwiązań interpretacyjnych.

W świetle powyższego, wydaje nam się, że dobry model hermeneutyczny, obrazujący dynamikę symbolizmu biblijnego i jego ścisły związek z sensem dosłownym tekstu, zawarty został w maksymie Grzegorza Wielkiego: „Divi-

${ }^{6}$ R.E. Brown - S.M. Schneiders - M. Wojciechowski, Hermeneutyka biblijna 30-37, w: Katolicki Komentarz Biblijny, red. R.E. Brown - J.A. Fitzmyer - R.E. Murphy, red. naukowa wyd. pol. W. Chrostowski, Warszawa 2001, 1796-1810 (Sensy ponaddosłowne).

7 Por. Dei Verbum 12; KKK 111. 
na eloquia cum legente crescunt" (Słowo Boże wzrasta wraz z czytającym). Metafora wzrostu łączy szereg współzależnych elementów i charakterystyk.

Po pierwsze, w jakiś sposób odwołuje się do 1Kor 3, 6: „Ja siałem, Apollos podlewał, lecz Bóg dał wzrost". Św. Paweł nie precyzuje szczegółowo, co kryje się w metaforze siania, podlewania $\mathrm{i}$ wzrostu, jednak na podstawie przypowieści o siewcy (Łk 8,4-21) możemy odnieść tę metaforę do przekazu Słowa Bożego, zwłaszcza że w 1Kor 3,9 adresaci nauczania nazwani zostali uprawna rola (por. Łk 5,15). Możemy więc powiedzieć, że Słowo Boże, z chwilą gdy zostało zinterioryzowane przez odbiorcę, staje wobec szansy wzrostu. Sprawcą tego wzrostu jest Duch Święty, natomiast sam odbiorca przesłania pełni również niebagatelną rolę, na którą wskazują nam alegorie zaproponowane przez Jezusa, kryjące się w obrazach skały, cierni, drogi, i w końcu żyznej gleby.

Po drugie, alegoria wzrostu pozwala nam na organiczne polączenie sensu dosłownego, którym można by nazwać ziarno w momencie rzucenia w glebę, $\mathrm{z}$ sensem ponaddosłownym, którym będzie okazałe drzewo. Drzewo genetycznie jest zawarte w nasieniu, jednak stanowi samo w sobie odrębny byt, podobnie jest $z$ sensem ponaddosłownym $w$ relacji do sensu wyrazowego. Sens ponaddosłowny zawiera w sobie nową jakość, jednak tylko w pewnym sensie można mówić o procesie twórczym. Tak jak gleba dostarcza nasieniu soli mineralnych koniecznych do wzrostu oraz tworzy środowisko, w którym wzrost ten może się dokonać, podobnie odbiorca tekstu natchnionego obejmuje tekst biblijny swoją mentalnością, przed zrozumieniem i horyzontem lingwistycznym.

Nietrudno się zorientować, że interpretacja nakierowana na ponaddosłowne odczytanie tekstu kryje w sobie szereg zagrożeń i niebezpieczeństw. Wiadomo, że opory i podejrzliwość wobec alegorycznego odczytywania Biblii towarzyszyły historii egzegezy od czasów św. Hieronima aż po dzień dzisiejszy. Nie były one i nie są bezpodstawne. Zwłaszcza dzisiaj, kiedy taka metoda interpretacji Biblii traktowana jest przez wielu jako anachronizm. Stąd też ważne wydaje się wyświetlenie zagrożeń towarzyszących jej stosowaniu w czasach dzisiejszych.

Pierwszym zagrożeniem może być deprecjacja wymiaru historycznego i sensu dosłownego Pisma Świętego. Często medytacja nad tekstem biblijnym w oparciu o alegorię zaczerpniętą z dzieł Orygenesa lub Bernarda z Clairvaux, zwłaszcza w przypadku tekstów starotestamentalnych, może wydać się bardziej owocna i inspirująca niż poszukiwanie dosłownego znaczenia tekstu. Czytając, dajmy na to, komentarz Orygenesa do Rdz 21,14-19, jeżeli odniesiemy obraz studni wody żywej do Słowa Bożego, zaś otwarcie oczu Hagar do daru łaski, który uzdalnia nas do czerpania $\mathrm{z}$ niej orzeźwiającego napoju ${ }^{9}$, wówczas opi-

${ }^{8}$ Homiliae in Ezechielem I 7, 8, SCh 327, 244. Zdanie zacytowane w KKK 94.

${ }^{9}$ Por. Origenes, In Genesin hom. 7, 6, SCh 7bis, 210, thum. pol. S. Kalinkowski, PSP 31/1, 89. 
sana historia zaczyna mieć głębsze znaczenie dla czytelnika. Pozostając natomiast jedynie na poziomie sensu dosłownego, mamy przed oczyma wydarzenie, które stanowi co najwyżej etiologiczny opis pochodzenia Izmaelitów. Bogactwo duchowych treści zawarte w spuściźnie alegorycznej interpretacji Biblii może przyćmić $w$ świadomości czytelnika znaczenie historyczne wydarzeń opisywanych na kartach Pisma Świętego. U chrześcijan nie obeznanych z problematyką nocmatyczną Biblii może wytworzyć się przekonanie, że historyczny wymiar dziejów zbawienia jest drugorzędny względem symboli odczytywanych na kanwie tych wydarzeń. Takie rozumienie Biblii redukowałoby rolę faktów zbawczych do rangi nośników ponadczasowych treści, i to nośników nie mających w samych sobic istotnego znaczenia, co zwlaszcza w odniesieniu do osoby Jczusa Chrystusa mogłoby mieć opłakane konsekwencje.

Drugim zagrożeniem może być niebezpieczeństwo postawy „gnostyckiej” wobec tekstu Pisma Świętego. Ponaddosłowne odczytywanie Biblii zawsze w tradycji Kościoła obwarowane było koniecznością gruntownego przygotowania i zapoznania się z wcześniejszym dorobkiem pisarzy uznawanych za autorytety. Stanowiło ono swoistą duchową spuściznę. Ponadto już od najdawniejszych czasów uważano, że umiejętność alegorycznej lektury Biblii zarezerwowana jest dla szczególnego rodzaju chrześcijan. Orygenes sugerował, jakoby znaczenie dosłowne było zarezerwowane dla ludzi cielesnych, moralne - dla tych, którzy zaczęli czynić postępy w życiu duchowym, natomiast alegoryczne dla doskonałych ${ }^{10}$. Najdalej idące konsekwencje takiego podejścia możemy znaleźć w postawie niektórych gnostyków chrześcijańskich, dla których miernikiem doskonałości duchowej lub pozycji w społeczności było wtajemniczenie w coraz głębsze znaczenia tekstu biblijnego, czyli pozyskiwanie szczególnego rodzaju wiedzy. Umberto Eco, analizując to zjawisko z perspektywy hermencutycznej, używa określenia syndrom tajemnicy. Polega on na swoistej relacji czytelnika do tekstu, która cechuje się tym, ze „,czytelnik jest trawiony podejrzeniem, że każda linijka tekstu zasłania inne, tajemne znaczenie; słowa, zamiast mówić, ukrywają to, co niewypowiedziane" ${ }^{, 1}$. Takie podejście do tekstu biblijnego sprawia, że czytelnik traktuje go $z$ wielkim pietyzmem, jako coś, co zawiera w swoim wnętrzu niezliczone tajemnice i duchową głębię. Owszem, postawa szacunku wobec Biblii jest czymś ze wszech miar pożądanym, lecz należy zastanowić się nad powodem owego szacunku. Jeżeli czytelnik traktuje Słowo Boże jak przedmiot magiczny, wówczas naraża się na niebezpieczeństwo mniej lub bardziej świadomego kształtowania swojego podejścia hermeneutycznego w duchu gnostyckim. Dalszą konsekwencją takiego podejścia może

${ }^{10}$ Por. Origenes, De principiis IV 4, 11, SCh 268, 310-312, tłum. pol. S. Kalinkowski, PSP 23, 301.

11 U. Eco, Interpretacja i nadinterpretacja, tlum. T. Bieroń, Kraków 1996, 40. Na temat określenia syndrom tajemnicy, zob. tamże, 39. 
być wykształcenie się w świadomości czytelnika przekonania, jakoby posiadł w końcu prawdziwe rozumienie Biblii, którego pozbawieni są inni jej odbiorcy. Prowadzić to może do zgubnych skutków na płaszczyźnie eklezjologii, a mianowicie do takiego postrzegania struktury i przynależności do Kościoła, którego kryterium byłby stopień rzekomego wtajemniczenia w pojmowanie duchowego sensu Biblii.

Trzecim zagrożeniem jest niebezpieczeństwo subiektywizmu. O ile postawa „gnostycka" stanowila niejako przejaskrawienie tradycji i autorytetów, o tyle jest możliwe odchylenie w przeciwną stronę, mianowicie w kierunku subiektywizmu. Gnostyk przypisywal mistyczną, niemalże nieomylną wartość interpretacji odsłoniętej przed nim przez duchowego przewodnika, mającego prerogatywy guru. Dla niego autorytet i tradycja, zakreślone oczywiście ramami ugrupowania, z którym czuje się związany, miały charakter normatywny. W przypadku subiektywizmu nie posiadają one żadnej wartości. Subiektywne odczytywanie Biblii bazuje na przekonaniu, że kryterium poprawnej interpretacji znajduje się w samym czytelniku. On sam decyduje o tym, jak należy rozumieć tekst, opierając uwierzytelnienie własnych intuicji w przeświadczeniu, że są one kierowane przez Ducha Świętego. Papieska Komisja Biblijna zwraca uwagę na to, ze „relektury” Biblii w nowych okolicznościach mogą sprzyjać „przypisywaniu tekstom biblijnym jakiegokolwiek sensu, interpretując go w sposób całkiem subiektywny" ${ }^{\prime 2}$. Niebezpieczeństwo subiektywizmu wydaje się też być głównym argumentem dla tych, którzy w sposób krytyczny podchodzą do alegorycznego odczytywania Biblii. Takie jej interpretowanie według S. Amslera - pozwala na niekontrolowane posługiwanie się własną wyobraźnią $^{13}$.

Niewątpliwie ponaddosłowne odczytywanie Biblii ma charakter twórczy i nie można całkowicie pozbawić go wymiaru subiektywnego, przynajmniej na etapie powstawania określonej interpretacji. Również nie można zanegować swoistego oddziaływania Ducha Świętego na czytelnika, który w sposób szczery, z pokorą, dysponując odpowiednim przygotowaniem biblijnym i w jedności $z$ tradycją i magisterium Kościoła stara się w sposób oryginalny odczytać dany passus biblijny. Dlatego też wydaje się, że zdrowa interpretacja ponaddosłowna nie zaklada negacji subiektywizmu jako takiego, ale - co słusznie precyzuje Papieska Komisja Biblijna - ,niekontrolowanego subiektywizmu" (subjectivisme incontrôlable $)^{14}$. Sądzimy, że owa zalecana przez magisterium Kościoła kontrola polega przede wszystkim na stosowaniu szeregu kryteriów, spośród których następujące jawią się jako szczególnie istotne.

12 Interpretacja Biblii w Kościele, s. 63.

13 Por. S. Amsler, L'Ancien Testament dans l'Église, Neuchâtel 1960, 170.

14 Por. L'interpretation de la Bible dans l'Église, „Biblica” 74 (1993) 490; Imerpretacja Biblii w Kościele, s. 63. 
Pierwszym i najważniejszym kryterium interpretacji ponaddosłownej wydaje nam się nicsprzeczność względem znaczenia dosłownego tekstu. Alegoria może rozwijać sens tekstu, budować nowe płaszczyzny znaczeniowe, ale nie może wprowadzać takich treści, które w jakiś sposób niweczyłyby pierwotne przesłanie wynikające $\mathrm{z}$ kontekstu historycznego i według wszelkiego prawdopodobieństwa zamierzone przez autora natchnionego. Wyraźnie sformułował tę zasadę Tomasz z Akwinu ( $†$ 1274): „Wszystkie sensy [tekstu biblijnego] opierają się na jednym - dosłownym" ". Zasada ta była powtarzana w późniejszych wypowiedziach Magisterium Kościoła ${ }^{16}$ oraz opracowaniach teologicznych ${ }^{17}$. Oczywiście sformułowanie „,undentur super litteram” może być rozumiane w sposób wąski lub szeroki. Wyważona wydaje nam się opinia P. Grecha, według którego znaczenie ponaddosłowne powinno odznaczać się przynajmniej pewną analogią względem znaczenia dosłownego tekstu, by nie zostało uznane za dziwaczne ${ }^{18}$.

Drugie kryterium związane jest z eklezjalnym wymiarem tradycji chrześcijańskiej alegorystyki. Od samych początków interpretacja ponaddosłowna pojmowana była nie jako indywidualna twórczość określonego komentatora, lecz jako część spuścizny Kościoła przekazywanej z pokolenia na pokolenie. I właśnie stąd, a nie $z$ samego faktu takiego lub innego odczytania treści tekstu wynikała jej wiarygodność. Łączyło się to z przeświadczeniem, że Jezus Chrystus jest obecny i działa w dziejach Kościoła, zatem jeżeli dana interpretacja pojawiała się u autorów wcześniejszych i była powtarzana przez innych, świadczyło to, ze zawiera ona takie przesłanie, które jest zgodne z Bożymi planami zbawienia. Nie oznaczało to ślepego i bezwolnego powtarzania wcześniejszych wzorców, lecz sklaniało do ich znajomości i ustosunkowania się do nich. Jest to widoczne zwłaszcza u pisarzy średniowiecznych, którzy zanim podejmowali się trudu alegoryzacji, musieli poznać wcześniejsze komentarze.

Owa ciągłość tradycji wydaje się głównym miernikiem wartościującym poszczególne alegorie. Oczywiście Orygenes i najwcześniejsi komentatorzy mogli pozwolić sobie na większą swobodę, ale również w ich pismach raz po raz pojawia się nuta pokory, kierująca wzrok czytelnika nie na indywidualnego autora, ale na Kościół. Kryterium tradycji nie ogranicza się tylko do wymiaru arytmetycznego. O wartości danej alegorii nie decyduje tylko ilość komenta-

15 „Omnes sensus fundentur super unum, scilicet litteralem” (Summa Theolgica 1 1, 10, ad 1).

16 Por. np. Benedykt XV, Spiritus Paraclitus; EB 485-486

17 Por. J.A. Fitzmyer, Pismo duszq teologii, tłum. A. Baron - M. Dobrzyniak, Kraków 1997. 66. Z perspektywy tradycji patrystycznej przedstawia ją S. Haręzga, En Pnetımati jako zasada interpretacji Pisma Świętego we wschodniej tradycji Kościoła, RBL 43 (1990) 114-115.

${ }^{18}$ Por. P. Grech, The "Regula fidei" as hermeneutical principle yesterday and today, w: $L$ 'interpretazione della Bibbia nella Chiesa. Atti del Simposio promosso dalla Congregazione per la Dottrina della Fede (Roma, settembre 1999), Città del Vaticano 2001, 216: „A figurative exegesis should at least show some analogy with the literal reading so as not to become fanciful". 
torów, w których dziełach ona powraca. ale również ich autorytet. Stąd też najwyższą wartość miały te alegorie, które znalazły swój wyraz w liturgii lub wywodzą się od najbardziej cenionych autorów, takich jak Ambroży ( $†$ 397), Jan Chryzostom ( $\uparrow 407)$, Hieronim ( $\uparrow 419)$, Augustyn ( $† 430)$ i Grzegorz Wielki († 604). Papież Leon XIII w encyklice Providentissimus Deus w sposób syntetyczny przedstawił najważniejsze autorytety egzegetyczne starożytności i średniowiecza, wskazując krótko na ich zasługi ${ }^{19}$. Czasami jednak dzieła przypisywane tym autorom miały charakter pseudoepigraficzny, dlatego też - być może - w naszych czasach, kiedy badania nad atrybucją starożytnych komentarzy pozwalają nam znaleźć się w pozycji uprzywilejowanej względem uczonych ubiegłych stuleci, mamy szansę, by przedstawione tu kryterium stało się wyraźniejszc i bardziej odpowiadające faktycznemu autorstwu starożytnych tekstów. Zresztą już sam fakt przypisania określonej interpretacji któremuś ze starożytnych autorytetów świadczy o jej randze w danym środowisku lub epoce. Ciągłości przekazu tradycji alegorycznej towarzyszyły niejednokrotnie interesujące zjawiska. Najważniejszym jest chyba koegzystencja różnorodnych tradycji. Określony fragment mógl być interpretowany na kilka sposobów i często ten sam autor odczytywał go inaczej w zależności od potrzeby duszpasterskiej lub własnego doświadczenia duchowego $w$ określonym momencie. Czasami komentatorzy zestawiają dwie lub trzy interpretacje, nie wskazując na przewagę którejkolwiek, innym zaś razem znajdujemy opinie wartościujące poszczególne alegorie. Opinie te często kształtowały podejście do tekstu późniejszych autorów.

W niektórych przypadkach szczególnie trafna alegoria zyskiwała sobie prawo wylączności i wszyscy praktycznie komentatorzy pozostawali jej wierni. Wydaje nam się, że w tym względzie daje się zaobserwować pewna prawidłowość: im więcej było różnorodnych interpretacji danego tekstu, tym bardziej wyzwalało to inicjatywę twórczą u innych komentatorów. Na przykład, motyw pięciu chlebów z perykopy o cudownym nakarmieniu tłumów został praktycznie zdominowany odniesieniem do Pięcioksięgu Mojżesza, podczas gdy sąsiadujący $\mathrm{z}$ nim motyw dwóch ryb doczekał się kilkudziesięciu przynajmniej odrębnych znaczeń. W tym miejscu dotykamy problemu wprowadzania nowych interpretacji $\mathrm{w}$ krwioobieg chrześcijańskiego symbolizmu. Większa lub mniejsza oryginalność zależały nie tylko od osobowości autora, ale również od czasów, w jakich żył i - przypuszczalnie - od jego własnej pozycji w Kościele. Na przykład VIII-X wieku, czyli okres pomiędzy wielkimi epigonami czasów patrystycznych a złotym wiekiem piśmiennictwa średniowiecznego, stanowił raczej czasy, w których powtarzano i tworzono kompila-

${ }^{19}$ Por. Providentissimus Detus (18 XI 1893), jej tekst w: Leonis XIII Pontificis Maximi Acta, t. 13, Roma 1894, 326-364; ASS 26 (1893-1894) 269-292; EB 91-96; tłum. i przedmowa J. Archutowski: Encyklika papieża Leona XIII „Providentissimus Deus”, Kraków 1934. 
cje. Natomiast komentatorzy, którzy już za życia cieszyli się autorytetem wśród współczesnych, tacy jak Grzegorz Wielki ( $†$ 604) lub Bernard z Clairvaux $(\dagger 1153), z$ rozmachem rozwijali oryginalne skojarzenia symboliczne, przewidując być może, że po ich śmierci wpiszą się one na stałe w nurt tradycji. I w końcu spotykamy tradycje interpretacyjne, które w pewnym momencie historii przygasły lub odeszły do lamusa, czy to z tego powodu, że zmieniły się warunki historyczne (na przykład alegorie dotyczące ewangelizacji ludów pogańskich w środowiskach schrystianizowanych), czy też pewne kwestie filozoficzne lub dotyczące szerzej pojętej mentalności przestały ludzi po prostu interesować. Na ich miejsce pojawiały się nowe, często stanowiące modyfikacje wcześniejszych, dając barwne świadectwo temu, co to znaczy, ze sens ponaddosłowny Biblii wzrastat wraz z czytajacymi.

Wydaje się, że - w przeciwieństwie do czasów obecnych - starożytność i średniowiecze w sposób naturalny „oczyszczały” literaturę przekazywaną z pokolenia na pokolenie. Przetrwały tylko te komentarze, które kopiści uznali za ważne na tyle, by poświęcić im trud przepisania. Inne teksty, które zostały gorzej ocenione, popadły w zapomnienie. Oczywiście jest to uwaga, która zawiera tylko cząstkę prawdy, gdyż na transmisję spuścizny piśmienniczej wpływało równieź wiele innych elementów. Tym niemniej, przynajmniej w przypadku tradycji alegorystyki chrześcijańskiej, nawet sam fakt, że dane dzieło zostało raz czy kilkakrotnie przepisane, świadczy o pewnym jego autorytecie, przynamniej w określonym środowisku monastycznym, gdyż właśnie tam głównie dokonywał się ów przekaz.

Trzecie kryterium związane jest z pojęciem regula fidei. Wprawdzie okreś-

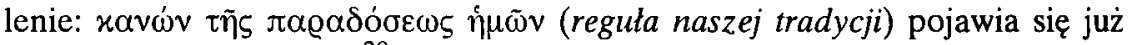
u Klemensa Rzymskiego ${ }^{20}(\dagger 101)$, niemniej dopiero na kartach dzieł Ireneusza († ok. 202) zyskuje znaczenie teologiczne. Biskup Lyonu, pisząc Adversus haereses, zwraca uwagę na specyficzną interpretację Pisma Świętego uwarunkowaną filozoficznymi systemami gnostyków, z którymi prowadzi polemikę. Przeciwstawia jej $z$ jednej strony kontekst literacki interpretowanej perykopy, $\mathrm{z}$ drugiej zaś regułę wiary warunkującą właściwe zrozumienie tekstu. Tą regułą wiary jest kompendium prawd stanowiących kerygmat chrześcijański, które w czasach Ireneusza nie zostało jeszcze w sposób oficjalny sformułowane w postaci $c r e d o^{21}$. W podobnym znaczeniu używa terminu xavóv Orygenes († 254). Pisząc o „regule niebiańskiego Kościoła Jezusa Chrystusa, według nauki Apostołów"22, kładzie on nacisk na ciągłość przekazu wiary, począwszy od nauczania Chrystusa, przez Apostołów, aż po Kościoły założone przez nich.

${ }^{20}$ Por. Epistula ad Corinthios 7, 2, SCh 167, 110, tłum. A. Swiderkówna, BOK 10, 54.

${ }^{21}$ Por. Grech, The „Regula fidei” as hermeneutical principle, s. 208-209. Tam tez liczne odniesienia do dzieł Ireneusza.

${ }^{22}$ De principiis IV 2, 2, SCh 268, 300, tłum. S. Kalinkowski, PSP 23, 297-297. W tekście podaliśmy jednak tłumaczenie własne). 
To właśnie Kościoły szczycące się apostolskim pochodzeniem oraz te, które pozostają z nimi w jedności, stanowią gwarancję i ostoję właściwej interpretacji Biblii.

W tradycji łacińskiej określenie regula fidei pojawia się często u Tertuliana ${ }^{23}$ († ok. 220), lecz jako pojęcie używane w znaczeniu teologicznym wielokrotnie powróci na kartach dzicł Augustyna ${ }^{24}(\dagger 430)$. Określenie to jest trudne do przełożenia. Przeważnie w polskich tłumaczeniach pojawia się kalka językowa $\mathrm{z}$ łaciny reguta wiary, choć spotkaliśmy się (co zaznaczono w ostatnim przypisie) $\mathrm{z}$ innymi przekładami, jak fundament wiary lub prawda wiary. Regułą wiary można by zatem nazwać całość prawd zawartych w doktrynie chrześcijańskiej, niekoniecznie zawartych w Credo lub sprecyzowanych dogmatycznie. Reguła wiary nie jest określona w sposób precyzyjny, często może być wyczuwana intuicyjnie przez tego, kto żyje według Ducha Chrystusowego i w jedności z Kościołem oraz w sposób spójny wynika z dosłownego sensu Pisma Świętego.

Alegoryczna interpretacja określonego tekstu nie może zawierać treści sprzecznych z szeroko pojętą regula fidei. Jeżeli takowe pojawią się, choćby w implikacjach wynikających z zestawienia alegorii z kontekstem, sensem doslownym lub innymi symbolami uznawanymi powszechnie przez tradycję Kościoła, wówczas należy ją odrzucić. Regula fidei nie stanowi jednak tylko krytcrium negatywnego. W sposób pozytywny stwarza swoiste środowisko myślowe - poza samym kontekstem literackim dzieła oraz kontekstem kanonicznym zbioru Pism natchnionych - wewnątrz którego dany passus biblijny zyskuje znaczenie $^{25}$.

$\mathrm{Z}$ kryterium reguły wiary organicznie związane są dwa inne kryteria, mianowicie lex orandi oraz sensus fidelium. Lex orandi podkreśla znaczenie liturgii oraz szerzej, duchowy wymiar reguły wiary. Kontekstem bowiem, wewnątrz którego tekst biblijny zyskuje znaczenie, jest nie tylko nauczanie i głoszenie, ale również praktyka życia Kościoła, której culmen et fons jest liturgia. Zwłaszcza po odnowie liturgicznej Soboru Watykańskiego II, która znacznie rozszerzyła zakres tekstów biblijnych czytanych podczas Mszy Świętej oraz innych sakramentów, staje się czymś istotnym taka ich interpretacja, która wpisywałaby się

${ }^{23}$ Por. De praescriptione haereticorum 12, 13, CCL 1, 197, thum. E. Stanula, PSP 5, 51; Adversus Praxean 3, 1, CCL 2, 1161; Adversus Marcionem IV 2, 5, CCL 1, 548, tłum. T. Ryznar, PSP 58,144 .

${ }^{24}$ Augustyn, Confessiones VIII, 12, CCL 27, 132, tłum. Z. Kubiak, Warszawa 1987, 188 (fundament wiary); De doctrina christiana III 2, 3, CCL 32, 78, tłum. J. Sulowski, PSP 22, 72 (prawda wiary); De consensu Evangelistarum I 1, 2, CSEL 43, 3, tłum. J. Sulowski, PSP 50, 18 (regula wiary); Contra Julianum II 5, 10, PL 44, 680, thum. W. Eborowicz, PSP 19, 142 (regula wiary); passim. Zagadnieniu reguly wiary w pismach Augustyna poświęcil niedawno rozprawę doktorską, obronioną na Augustinianum, W. Dawidowski, The Rule of Faith in the theological method of Augustine of Hippo, Roma 2001 (opublikowany w 2002 ekstrakt, pod tym samym tytułem, obejmuje: wstęp, rozdziały 7 i 8 oraz konkluzję).

${ }^{25}$ Por. Grech, The "Regula fidei" as hermeneutical principle, s. 222. 
w kontekst okresu liturgicznego, danego święta oraz brałaby pod uwagę relacje względem innych czytań biblijnych, które im towarzyszą. Ten kontekst często skłania do tworzenia znaczeń ponaddosłownych, które wyrażałyby, uwydatniaky i ubogacały treści związane ze sprawowaną liturgią. Na przykład lektura nawiązująca do epizodu z manną na pustyni (Pwt 8, 2-3. 14b-16a), przeznaczona na uroczystość Najświętszego Ciała i Krwi Chrystusa, zaprasza do odczytania symbolu pokarmu, jakim Bóg obdarzył Izraelitów podczas wędrówki do Ziemi Obiecanej, jako Eucharystii. Podobnie czytanie opisujące wprowadzenie Arki Przymierza do Jerozolimy (1Krn 15, 3-4. 15-16; 16, 1-2), przeznaczone na uroczystość Wniebowzięcia Najświętszej Maryi Panny, sugeruje odczytanie motywu literackiego Arki w odniesieniu do Matki Chrystusa, a co za tym idzie, Jerozolimy jako niebios, natomiast akcji przeniesienia Arki jako Wniebowzięcia, co w rezultacie nada słowom mówiącym o ,przeniesieniu Arki Pana na jej miejsce, które dla niej przygotowal" $(1 \mathrm{Krn} 15,3)$ całkiem nowe znaczenie, oczywiście niezamierzone przez lewitę żyjącego w IV-III wieku przed Chrystusem, uważanego za autora Ksiąg Kronik.

Drugim kryterium związanym $z$ regułą wiary jest sensus fidelium, czyli swoisty zmysł wiary właściwy wszystkim ochrzczonym. Wspomina o nim wielokrotnie Augustyn. Wedlug niego wszyscy chrześcijanie szczerze żyjący według Ewangelii, nawet nie posiadający głębszej znajomości Biblii i doktryny Kościoła, „troskliwie zabiegający o regułę wiary, trzymają się jej bardzo mocno"26. Ów zmysł wiary ma wymiar globalny, obejmujący Kościól jako całość, nie musi zaś z konieczności i automatycznie dotyczyć każdego poszczególnego chrześcijanina, który podatny jest na popełnianie błędów, co zresztą zaznacza Augustyn w dalszej części zacytowanej powyżej wypowiedzi. Wówczas zadaniem tych, którzy piastują władzę w Kościele jest jak najszybsze upomnienie go i poprawienie. Kim są jednak ci, których Augustyn nazywa auctoritas catholica i przyznaje im szczególne prerogatywy, by czuwać nad poprawnością reguły wiary? Dla Orygenesa byli to przełożeni kościołów o rodowodzie apostolskim oraz wspólnot będących z nimi w jedności. Wśród nich szczególne miejsce przysługiwało biskupowi Rzymu, będącemu następcą apostoła Piotra, któremu Jezus powierzył specjalne uprawnienia (Mt 16,18-19). Rola auctoritas catholica w odniesieniu do hermeneutyki biblijnej sensu ponaddosłownego może być postrzegana w wymiarze restrykcyjnym, na który w zacytowanym fragmencie kładzie nacisk Augustyn, oraz pozytywnym, jako promowanie pewnych rozwiązań hermeneutycznych.

Czwartym kryterium jest użyteczność duchowa, która aczkolwiek nie jest intersubiektywnie sprawdzalna, stanowi rację bytu interpretacji ponaddosłownej. Tworząc wyszukane alegorie pisarze chrześcijańscy mieli na celu wydobycie $\mathrm{z}$ niej jak najwięcej treści mogącej mieć zastosowanie w homiliach, kate-

${ }^{26}$ De baptismo V 27, 38, CSEL 51, 295. 
chezach bądź naukach ascetycznych. Wymiar użyteczności duchowej staje się fundamentalny zwłaszcza u pisarzy średniowiecznych ze środowisk zakonnych. Jest to związane $\mathrm{z}$ codzienną praktyką lectio divina, która miała pobudzać czytelnika do kształtowania własnego wnętrza przy pomocy obrazów i treści biblijnych. $\mathrm{D}$. Gorce w dziele poświęconym początkom praktyki lectio divina podkreśla, iż pomiędzy mnichem a księgą Biblii powstawał rodzaj tajemniczej duchowej komunikacji, ciągła wzajemna wymiana poufnych zwierzeń, intymność, która stanowiła słodki owoc ich wzajemnego zjednoczenia ${ }^{27}$. Lektura prowadząca poprzez medytację nad Słowem Biblii do kontemplacji tajemnic Bożych niejako skłaniała do kojarzenia motywów literackich tekstu natchnionego $\mathrm{z}$ wielorakimi aspektami życia duchowego mnicha.

O ile badanie dosłownego sensu Pisma Świętego wymaga od biblisty przede wszystkim kompetencji naukowej i może być prowadzone przez osoby wyznające inne religie, a nawet o światopoglądzie laickim, o tyle praca nad duchowym sensem Biblii zakłada pogłębione chrześcijańskie życie duchowe, związane właśnie $\mathrm{z}$ owym subiektywnym wymiarem sensu ponaddosłownego. $\mathrm{Z}$ tego też względu Pius XII w instrukcji o właściwym nauczaniu Pisma Świętego zamieszcza następujące zalecenie, skierowane pod adresem wykładowców biblistyki: „Sens duchowy, z taką wielką troską i milością przez Ojców Kościoła i wielkich interpretatorów wyjaśniany, wykładowca tym łatwiej zrozumie i tym bardziej w sposób pobożny przedstawi uczniom, im bardziej sam będzie przyozdobiony czystością serca, wzniosłością myśli, pokorą ducha, szacunkiem dla Boga objawiającego się oraz miłością"28.

Duchowa perspektywa lektury Pisma Świętego odzwierciedla jeszcze jeden wymiar życia Kościoła, mianowicie posługę duszpasterską i przepowiadanie. Alegorystyka miała służyć nie tylko pożytkowi duchowemu samego interpretatora, lecz posługiwał się on tą metodą w swej działalności pastoralnej, bowiem większość starożytnych komentatorów Biblii byla równocześnie biskupami lub kapłanami. To, co możemy nazwać instrumentalizacją tekstu biblijnego, wynikało z nadrzędnego scopos lektury Pisma Świętego, jakim była cura animarum.

Jako piąte kryterium możemy wyróżnić jedność Biblii. Pismo święte postrzegane było przez Ojców Kościoła i tradycję średniowieczną jako jedna księga, mająca jednego autora i jeden wątek tematyczny. Tym autorem pierwszorzędnym jest oczywiście Bóg, zaś postacią, wokół której obraca się i ku której prowadzi cały wątek literacki, jest Jezus Chrystus. Zasadę tę przypomina dziś Katechizm Kościoła Katolickiego, przytaczając Hugona ze św. Wiktora († 1141): „Całe Pismo święte jest jedną księgą, a tą jedną księgą jest Chrystus,

${ }^{27}$ Por. D. Gorce, La lectio divina des origines du cénobitisme à saint Benoît et Cassiodore. 1 . Saint Jérôme et la lecture sacrée dans le milieu ascétique romain, Paris 1925, s. XVII.

28 Instructio de Scriptura Sacra recte docenda (13 V 1950), AAS 42 (1950) 495-505 (cały tekst); EB 599 (sensus spiritalis). 
ponieważ całe Pismo Świçte mówi o Chrystusie i całe Pismo Święte wypełnia się w Chrystusie"29. Niezależnie od chronologicznej kolejności poszczególnych pism, którcj świadomość posiadali starożytni komentatorzy, mimo iż nie zawsze zgadzała siç ona z faktyczną, historyczną precedencją, odczytywali oni teksty biblijne we wzajemncj korclacji. Przejawiało się to zwłaszcza w dwóch wymiarach.

Po pierwsze, motywy literackie poszczególnych ksiąg składały się na świat przedstawiony całcj Biblii, niezależnie od tego, w jakim tekście występowały. Oznacza to, że znaczenie, jakie określona rzecz, wydarzenie lub postać posiadała w jednej księdze biblijnej, rzutowało na jej interpretację w innej księdze, napisanej przez innego hagiografa w innej epoce. Na przykład, glaz przykrywający otwór studni, o której czytamy w historii o Racheli i Jakubie (Rdz 29, 1-11), mógl być odczytywany w świetle symboliki głazu zamykającego wejście do grobu Chrystusa (J 20,1) lub też mógł symbolizować samego Zbawiciela, który nazywany był kamieniem węgiclnym (Mt 21, 42). W ten sposób powstawała cała sieć relacji znaczeniowych, które łączyły nie tylko poszczególne motywy literackie, lecz również całe epizody biblijne, pociągając za sobą dalsze interpretacje symboliczne.

Po drugie, szczególnym wymiarem jedności tekstu biblijnego była organiczna relacja pomiędzy Starym i Nowym Testamentem. Wyraził to św. Augustyn († 430) w słynnej sentencji: „Nowy Testament jest ukryty w Starym, natomiast Stary znajduje wyjaśnienie w Nowym"30. Jedność tę tradycja starożytna przedstawiała przy pomocy wielorakich alegorii, które starały się w różny sposób uzmyslowić wzajemną relację obu tych części Biblii. Stary i Nowy Testament tworzą razem szczypce $z$ brązu, przy pomocy których są skladane duchowe ofiary, symbolizowane ofiarami składanymi w świątyni Jerozolimskiej (Wj 27, 3; 38, 3). Są to dwa denary, które Jezus zostawił Kościołowi, by za nie leczył rany ludzkości (Łk 10,35). Są to dwie położne, które sprzeciwily się faraonowi, symbolizującemu szatana, i pomagają chrześcijanom rodzić się duchowo (Wj 1, 15-21). Stary i Nowy Testament symbolizowały wszystkie sprzęty Przybytku, występujące parami, a więc dwa ołtarze, dwie podstawy menory, dwie kurtyny składające się na zasłonę, itd. Wszystkie te alegorie w sposób wizualny pobudzaly wyobraźnię, chcąc wyrazić rozmaite aspekty wzajemnego związku pomiędzy Starym i Nowym Testamentem, którego najważniejszą konsekwencją są relacje o charakterze typologicznym.

Typologia stanowi niejako zwornik, łączący wewnątrz jednej historii zbawienia dzieje Starego i Nowego Przymierza. Typologia jako metoda interpretacyjna nie dotyczy tylko wybranych osób lub sytuacji, lecz stanowi swoisty klucz dla zrozumienia relacji pomiędzy Starym i Nowym Testamentem, który

${ }^{29}$ Hugo de S. Victore, De arca Noe morali 11 8, PL 176, 642C; KKK 134.

${ }^{30}$ Quaestiones in Heptateuchum 2, 73, CCL 33, 106, thum. J. Sulowski, PSP 46/1, 121. 
z jedncj strony wskazuje na wartość Starego Testamentu jako prefiguracji mistcrium Chrystusa, z drugiej zaś na nieaktualność dosłownego pojmowania przepisów Tory. Koncepcja ta, szczególnie widoczna w dziełach Orygenesa, miała równicż znaczenic apologetyczne w początkach chrześcijaństwa, w kontekście dyskusji z judaizmem, negującym znaczenic Nowego Testamentu, i z gnozą Marcjona, odrzucającą Stary Testament.

Ważną konsekwencją kryterium jedności Biblii jest to, że pozwala ono niektórym alegoriom zyskiwać rangę graniczącą z sensem dosłownym tekstu biblijnego. Dzieje się tak wówczas, gdy określony motyw literacki pojawia się w jakiejś księdze ubogacony o znaczenie przenośne zamierzone przez autora natchnionego, w podobny zaś sposób zostaje zinterpretowany przez tradycję $w$ innym passusie biblijnym. Na przykład, alegoria relacji małżeńskiej pomiędzy Chrystusem a Kościołem, występująca w Ef 5, 25-27 na poziomie przenośnego sensu wyrazowego, moze stanowić klucz dla zinterpretowania innych epizodów biblijnych, w których pojawia się relacja oblubieńcza. Obecnie powyższe kryterium jawi się jako zbieżne z założeniami tzw. kanonicznej metody analizy tekstu biblijnego ${ }^{31}$. Wychodzi ona z założenia, że przynależność poszczególnych ksiąg do kanonu Pisma Świętego stanowi tak ważne kryterium interpretacyjne, ze pozwala z perspektywy literackiej traktować Biblię jako jedną księgę. Jednak przedstawiciele tej metody, przeważnie reprezentujący biblistykę anglosaską (B.S. Childs, J.A. Sanders), nie odwołują się w swojej argumentacji do tradycji patrystycznej i średniowiecznej.

Starając się zatem dać odpowiedź na pytanie postawione w tytule artykułu, musimy wziąć pod uwagę hermeneutyczne podejście do tekstu biblijnego. Jeżeli kategorię sensu ograniczymy do historycznego, od-autorskiego znaczenia nadanego znakom lingwistycznym, skladającym się na tekst biblijny, wówczas alegorystyka wczesnochrześcijańska będzie postrzegana jako nadużycie, w najlepszym zaś wypadku jako akomodacja tekstu do potrzeb czytelnika. Jeżeli natomiast przyjmiemy dynamiczną koncepcję sensu jako tworu powstającego w dialogu tekstu z czytelnikiem, wykraczającego poza intencję autora, wtedy alegorystyka - zwłaszcza w jej szczególnej postaci, jaką jest symbolizm ma szansę na odnalezienie dla siebie miejsca również we współczesnych badaniach biblijnych ${ }^{32}$.

${ }^{31}$ Ogólnie na temat metody, zob. Interpretacja Biblii w Kościele, s. 40-42.

32 Problematyka przedstawiona w niniejszym artykule została omówiona szerzej w: K. Bardski, Pokarm i napój milości. Symbolizm w ponaddoslownej interpretacji Biblii w tradycji Kościoła, Rozprawy i Studia Biblijne 16, Warszawa 2004. 


\section{THE ALLEGORICAL EXEGESIS OF THE FATHERS - USE OR ABUSE OF THE BIBLICAL TEXT?}

\section{(Summary)}

The interpretation of the Bible throughout the centuries followed a twofold way: it consisted either in the research of the literal meaning connected with the intention of the author and the historical-cultural environment of the text, either in the morcthen-literal creative development of ideas associated with the literary motives of the text. The first kind of interpretation is considered fundamental for the biblical studies and makes use of the historical-critical method. The second one constitutes a very important stream in the tradition of the Church but has been scarcely analyzed from the point of view of the biblical studies.

In our paper we present some dangers connected with the more-than-literal interpretation. The most important could be the following: depreciation of the historical dimension of the biblical text and its literal meaning, a ,gnostic" attitude towards the spiritual sense and a subjective interpretation. We also propose some criteria of a legitimate more-then-literal creativity, based on the tradition of the Fathers of the Church and the medieval authors, namely: lack of inconsistency in relation with the literal meaning; tradition and authorities; the regula fidei (rule of faith); the spiritual usefulness; the unity of the Bible.

The answer to the question posed in the title depends on the hermeneutical approach to the biblical text. If the meaning of the text is considered as confined to the historical intention of the inspired author, then the more-then-literal creativity becomes an abuse of the text. If the meaning of the text is considered as a result of the dialogue between the text and the reader, than the allegorical interpretation appears as an interesting hermeneutical phenomenon worthy of scholarly research and exegetical practice. 